\title{
Preservation and Quality Evaluation of Sisnu (Urtica plaviflora) by Making Gundruk like Fermented Product
}

\author{
ACHYUT MISHRA ${ }^{1 *}$ and GANGA PRASAD KHAREL
}

\author{
Institute of Science and Technology, Central Campus of Technology, Dharan, Nepal
}

\begin{abstract}
Sisnu (nettle buds) of variety Urtica plaviflora, an under explored herb of Himalayan region, was preserved by fermentation followed by drying process and quality was evaluated. Chemical analyses of fresh Sisnu was found to be $84.4 \%$ moisture, 3.64g crude protein, $4.15 \mathrm{~g}$ ash, $1.66 \mathrm{~g}$ fiber, $0.52 \mathrm{~g}$ fat, $64.10 \mathrm{mg}$ potassium, $23.65 \mathrm{mg}$ calcium, $17.17 \mathrm{mg}$ Sodium and $32.12 \mathrm{mg}$ iron per $100 \mathrm{~g}$ samples on dry basis. The protein and potassium contents were found approximately six times higher than other leafy vegetables. In fermented product, ash, calcium and potassium contents were decreased significantly $(p<0.05)$. Fermentation was carried out as control, by adding 1\% salt, 1\% sugar and with the combination of $1 \%$ salt and $1 \%$ sugar. All fermented products have typical acidic flavor of Gundruk with additional putrid flavor. From the statistical analysis, color of the dried fermented products were significantly indifferent $(p>0.05)$ but flavor and test of salt and or sugar added products were significantly different $(p<0.05)$ from the control.
\end{abstract}

Keywords: Sisnu, Medicinal value, Fermentation, Sisnu-Gundruk, Drying

\section{Introduction}

Nettle buds (Nepalese tongue-Sisnu, Urtica Linn. of Urticaceae family), a genus of annual or perennial herbs, commonly known as nettle, distributed in the temperate and sub- tropical zones. Four common species of Urtica are used for vegetable purpose found in Indian region viz. dioica, girardinia, plaviflora and trema. All species are armed with stinging hairs on the leaves and stems, which on contact with the skin, cause irritation and symptoms and uritication or nettle-rash. The tender leaves of young shoots are cooked and eaten as a vegetable in the villages in the Himalayas. It has been also consumed in Iran and in certain parts of Europe and Africa. It is consumed as a vegetable alone or also mixed with cereals esp. millet flour to make porridge. It is known as a good source of protein, vitamins and minerals (Chopra et al., 1958). Some nettles, such as U. dioica and U. plaviflora, yield a fiber, which is said to rival the best hemp in strength. Some others varieties have been credited with diuretic properties in folk (Ayurbedic) medicine (Frohlich, 1997). The nettle fodder has reported a high biological value and recommended as a valuable chicken feed. It contains all the essential amino acids and the amount of bound amino acids is reported to be twice as high as alfalfa (Griffiths, 1966).

The species plaviflora (Nepal-Gharaiya-Sisnu) is a slender, sparingly branched, perennial herbs up to $3 \mathrm{~m}$ tall and copiously armed with stiff stinging hairs, abundantly found in the temperate region of Himalayas. Stems obtusely angled; leaves ovate or ovate chordate or lanceolate; flowers small, monoecious, green, clustered on lax axillaries cymes; achenes small with persistent sepals (Manandhar and Maheshwari, 2000).

\footnotetext{
* Corresponding author, E-mail: achyutmishra2000@gmail.com ${ }^{1}$ Present address: Food Research Unit, Nepal Agricultural Research Council (NARC)
}

The irritant property of species dioica has long beer used externally to excite activity in paralyzed limbs, and internally for the treatment of haematoptysis and other hemorrhages; there uses still survive in some parts of the western Himalayas. In addition to these long-time traditional uses, nettles are currently in use for the treatment of prostate problems. Germany has approved a mixture of saw palmetto and nettle root for the treatment of benign prostatic hyperplasia, which can develop into prostate cancer if left unattended. This mixture is also for sale in the United States. Clinical experiments of nettle has conformed the utility of the herb as haemostatic in vomiting of blood, uterine hemorrhage, and bleeding from the nose. The herb is also used in sciatica, palsy and rheumatism. Time-tested therapeutic applications range from flagellating oneself externally with nettle leaves on the skin, causing welts, to taking freeze-dried nettle leaf capsules internally. Nettles in the form of freeze-dried capsules are often recommended for asthma. Due its relatively high iron content, some cultures use stinging nettles as a remedy for anemia (Kavalali, 2003).

The tender leaves of species plaviflora are cooked and eaten as a green vegetable. Tender shoots and leaves are collected with the help of bamboo or iron pincers, and cooked as soup. The plant is boiled with maize, millet or wheat flour by adding salt and chili to make a sort of porridge, which is a favorite food item of the villagers (Manandhar and Maheshwari, 2000).

Generally herby vegetables are season oriented vegetable. Though Sisnu is taken as vegetable in our tradition by certain ethnic groups only however it contains some chief nutrients e.g. protein and minerals. Higher potassium content and many other minerals play a role of medicine for various diseases of human beings and other animals. So, to get this like vegetable in off-season it needs to preserve by any suitable means. 
Therefore the aim of the paper is to preserve Sisnu by the fermentation and drying process and to search its commercialization opportunities for both dried Sisnu and Sisnu-Gundruk (fermented Sisnu).

\section{Materials and Methods}

Materials: A common variety of nettle (Sisnu), Gharaiya (U. plaviflora) was collected from different part of Dhankuta district of Nepal. Four variations were made for fermentation with or without adding salt and sugar. Sugar was added to increase the acidity of Sisnu-Gundruk because sugar found in Sisnu was very low in comparison to other common leafy vegetables. Salt was added to enhance the halophilic lactic acid bacteria. Round amber glass bottle were used for pickling with its diameter of $80 \mathrm{~mm}$ and height of $150 \mathrm{~mm}$. The bottle had its neck diameter of $70 \mathrm{~mm}$ and plastic screw cap of $70 \mathrm{~mm}$ diameter.

Fermentation: The process of Gundruk making is quite simple. However, the preparation of Gundruk of superior quality merited an experienced hand. After selection of type of nettle, the green tender buds were than withered in the sun for 4 to 5 hours. Sun drying makes the buds tender, which in turn facilitates filling in the container. It was then crushed and shredded into small pieces. The crushing releases the juice on which fermentation occurs. It was then tamped in earthen pots and glass bottles and caped tightly (product formulation prior to fermentation is shown in Table 1). After the completion of fermentation, Sisnu-Gundruk was allowed for drying in sun. Only sun drying was performed to protect volatile acidic flavor rather than solar and mechanical driers.

All tightly packed containers were then kept undisturbed in a separate room under room temperature (i.e. $20^{\circ} \mathrm{C}$ to $22^{\circ} \mathrm{C}$ ) for proper fermentation. Temperature was checked daily until the fermentation was complete. Fermentation was completed after 2 weeks developing into the desired acidity. The first sign for fermentation was the forth that seeps from the vessel, and this was usually followed by a completion of fermentation judged by a typical sour and pleasant smell that comes off from the fermented products near to cap. From the $6^{\text {th }}$ days of fermentation, acidity (as lactic acid) of each fermented product was measured on each alternate day up to 15 days. Sensory analysis, acidity and $\mathrm{pH}$ were determined to find out the best sample among the four. The part of each product was taken for sensory evaluation as fresh and rest parts were dried with the sun until it becomes brittle. The dried Sisnu-Gundruk was packed in PE bags and sealed with electric heat sealer. Some part of prepared Gundruk was taken for sensory evaluation and the rest was put for the study of self life for 6 months where observation were carried out frequently in each interval of 1 month with sensory evaluation for flavor attribute and moisture content.
Table 1: Product formulation prior to fermentation

\begin{tabular}{cccc}
\hline Products & Sisnu \% & Salt \% & Sugar \% \\
\hline A & 100 & - & - \\
B & 99 & 1 & - \\
C & 99 & & 1 \\
D & 98 & 1 & 1 \\
\hline
\end{tabular}

Chemical analysis: The moisture content, total ash, minerals, crude fiber, crude protein, acidity, and $\mathrm{pH}$ were determined as described by Ranganna (2000).

Sensory evaluation: Sensory Evaluation of dried Sisnu and Sisnu-Gundruk was performed by making soup. As ingredients of soup, tomato powder (available in local market), mustard oil, turmeric powder and common salt $(2 \%)$ were taken in equal proportion for all variation. The minimum and maximum score given were 1 and 9 respectively. Therefore hedonic rating test as suggested by Ranganna (2000) was adopted as a method of evaluation.

Statistical analysis: The results were subjected to one way ANOVA for test statistics at $95 \%$ level of significance. LSD was used for mean comparison tests, where the test statistic was significantly different at 95\% level of significance (Ranganna, 2000).

\section{Results and Discussion}

Proximate and ultimate analyses of fresh Sisnu and dried Sisnu-Gundruk: Four common species of Urtica (Sisnu) are used for vegetable purpose found in Indian region viz. dioica, girardinia, plaviflora and trema. Only tender leaves with bud are used for vegetable purpose. Here the species, plaviflora, commonly used to consume as vegetable in Nepal, is taken for the testing material. So far as, chemical constituents of Sisnu are concerned, it was indeed a most interesting and curious aspect.

The crude protein content in Sisnu was found to be much higher $(30.25 \%$, shown in Table 2$)$ than the other leafy vegetable (rape leaves, 5.1\%, mustard leaves, $4.0 \%$ and Amaranth, 3.0\%). Moisture content in fresh leaves of Sisnu (84.4) is similar to other leafy vegetables comparing to rape leaves, $84.9 \%$ and so on. Regarding minerals only some important minerals have been determined in laboratory and shown in Table 2. Potassium content was found to be 470.70 $\mathrm{mg} / 100 \mathrm{~g}$ which is comparatively much higher than in other leafy vegetables and in blood $(20 \mathrm{mg} / 100 \mathrm{ml}$, Swaminathan, 2003). From the chemical analysis of fresh Sisnu and fermented Sisnu (Sisnu-Gundruk) (analyzed data shown in Table 2), there was found not significant difference in case of crude fiber, crude protein, crude fat, carbohydrate, sodium and iron content but found significant difference in case of ash, calcium and potassium content. The lower value of minerals found in case of Sisnu-Gundruk was due to leaching effect during fermentation where the soluble matters were lost. 
Mishra \& Kharel : J. Food Sci. \& Technol. Nepal, 6 (114-117), 2010

Table 2. Proximate composition and major minerals in fresh and fermented Sisnu

\begin{tabular}{|c|c|c|}
\hline \multirow[t]{2}{*}{ Parameters } & \multicolumn{2}{|c|}{ Values*(dry basis) } \\
\hline & Fresh & Fermented dried \\
\hline \multicolumn{3}{|l|}{ Proximate (g/100g) } \\
\hline Moisture & $84.40(0.02)$ & $11.12(0.04)$ \\
\hline Ash & $20.38^{\mathrm{a}}(0.098)$ & $12.24^{\mathrm{b}}(0.02)$ \\
\hline Crude fiber & $10.14^{\mathrm{a}}(0.12)$ & $8.82^{\mathrm{a}}(0.04)$ \\
\hline Crude Protein & $30.25^{\mathrm{a}}(0.16)$ & $29.76^{\mathrm{a}}(0.06)$ \\
\hline Fat & $3.30^{\mathrm{a}}(0.04)$ & $3.14^{\mathrm{a}}(0.02)$ \\
\hline Carbohydrate (total) & $33.30^{\mathrm{a}}(0.22)$ & $32.20^{\mathrm{a}}(0.16)$ \\
\hline \multicolumn{3}{|l|}{ Minerals (mg/100g) } \\
\hline Calcium & $187.90^{\mathrm{a}}(0.12)$ & $152.62^{\mathrm{b}}(0.06)$ \\
\hline Potassium & $470.70^{\mathrm{a}}(0.04)$ & $421.36^{\mathrm{b}}(0.04)$ \\
\hline Sodium & $107.31^{\mathrm{a}}(0.02)$ & $102.14^{\mathrm{a}}(0.22)$ \\
\hline Iron & $210.8^{\mathrm{a}}(0.06)$ & $208.32^{\mathrm{a}}(0.18)$ \\
\hline
\end{tabular}

*The figures in parentheses are the standard deviations of three repeated determinations. Superscripts in same alphabet are not significant and with different alphabet with each other are significant.

Table 3: Changes in pH of fermented Sisnu during fermentation

\begin{tabular}{clrrrr}
\hline \multirow{2}{*}{ Products } & \multicolumn{5}{c}{$\mathbf{p H} *$} \\
\cline { 2 - 6 } & \multicolumn{1}{c}{$\mathbf{6}^{\text {th }}$ day } & $\mathbf{8}^{\text {th }}$ day & $\mathbf{1 0}^{\text {th }}$ day & $\mathbf{1 2}^{\text {th }}$ day & $\mathbf{1 5}^{\text {th }}$ day \\
\hline $\mathbf{A}$ & $5.25^{\mathrm{a}}(0.05)$ & $5.20^{\mathrm{a}}(0.06)$ & $5.17^{\mathrm{a}}(0.08)$ & $5.09^{\mathrm{a}}(0.04)$ & $5.10^{\mathrm{a}}(0.06)$ \\
$\mathbf{B}$ & $5.20^{\mathrm{a}}(0.02)$ & $5.19^{\mathrm{a}}(0.08)$ & $5.17^{\mathrm{a}}(0.10)$ & $5.12^{\mathrm{a}}(0.12)$ & $5.14^{\mathrm{a}}(0.08)$ \\
$\mathbf{C}$ & $5.20^{\mathrm{a}}(0.12)$ & $5.18^{\mathrm{a}}(0.12)$ & $5.14^{\mathrm{a}}(0.10)$ & $5.12^{\mathrm{a}}(0.13)$ & $5.10^{\mathrm{a}}(0.04)$ \\
$\mathbf{D}$ & $5.17^{\mathrm{a}}(0.13)$ & $5.16^{\mathrm{a}}(0.10)$ & $5.13^{\mathrm{a}}(0.12)$ & $5.08^{\mathrm{a}}(0.08)$ & $5.09^{\mathrm{a}}(0.12)$ \\
\hline
\end{tabular}

* Means with same superscripts are not significantly different $(\mathrm{p}<0.05)$. The figures in parentheses are the standard deviations. A= 100\% Sisnu, B=99\% Sisnu and 1\% salt, C=99\% Sisnu and 1\% sugar and D= 99\% Sisnu with $1 \%$ salt and $1 \%$ sugar

Acidity and $\mathrm{pH}$ of fresh and fermented Sisnu: The $\mathrm{pH}$ of fresh Sisnu was been found to be 6.5. The $\mathrm{pH}$ of fermented products measured from $6^{\text {th }}$ days to $15^{\text {th }}$ days in regular interval of time is shown in Table 3. From statistical analysis it was found that there was no significant difference in $\mathrm{pH}$ of each variations of fermented Sisnu products ( $\mathrm{p}>0.05)$. It was found that the $\mathrm{pH}$ of each fermented products were decreased with time up to $12^{\text {th }}$ days followed by increased very slightly on $15^{\text {th }}$ days of fermentation.

The pattern of acid development is shown in Table 4, which (acidity of fresh Sisnu was found to be $0.2 \%$ as lactic acid) exhibited a trend with an initial rise from $6^{\text {th }}$ day followed by continuous increasing up to 12 days and remained constant or gradual decreased until 15 days. The test for acidity was carried out from $6^{\text {th }}$ day at an interval 48 hours. Optimum acidity of control sample was found to be $0.86 \%$ and the sample with $1 \%$ salt and $1 \%$ sugar was found to be 0.92 within 12 days

From statistical analysis it was found that there was significant difference in acidity in between sugar added and non added fermented Sisnu products $(\mathrm{p}<0.05)$ but there is no significant difference in final acidity of sugar and sugar plus salt added fermented Sisnu $(\mathrm{P}>0.05)$. The final acidity in fermented product after drying was decreased by $2.6 \%$. The acidity and $\mathrm{pH}$ of Sisnu-Gundruk was matched to medium acid-food $(\mathrm{pH}=$ 4.5 to 5.3 ). There was putrefied smell on the later stage of fermentation; it might be due to the degradation of protein (protein content is higher in Sisnu) to peptides and other nitrogenous constituents.

It was seen that there was no any effect in acidity in plain fermented and salt added fermented Sisnu (maximum acidity was developed in between 8 to 12 days) but it was found highest acidity in sugar added fermented Sisnu. In case of sugar added fermented Sisnu acidity increasing pattern was almost similar from 6 to 12 days. Lactic acid bacteria grow best at 18 to $22^{\circ} \mathrm{C}$ has good capability of attacking sucrose and fructose, producing acidity at initial stage of fermentation.

Sensory analysis: The sensory analysis result of SisnuGundruk products is shown in Table 5. There was no significant difference in color within the products $(p>0.05)$ but significant difference in flavor of sugar added and none added fermented products $(\mathrm{p}<0.05)$. It was also found a significance difference in taste between control product and products by adding salt and sugar $(\mathrm{p}<0.05)$. However, most of panelists preferred the product of $1 \%$ sugar (more acidic). There was almost same score for color of each variation but higher score for flavor were given to sugar and salt added product. From this data it was found that lactic acid was increased due to addition of sugar in product; however, both ingredients i.e. sugar and salt were responsible to enhance flavor and taste in the fermented products. 
Mishra \& Kharel : J. Food Sci. \& Technol. Nepal, 6 (114-117), 2010

Table 4. Changes in acidity (as lactic acid) during fermentation Sisnu with salt and sugar

\begin{tabular}{|c|c|c|c|c|c|}
\hline \multirow[t]{2}{*}{ Products } & \multicolumn{5}{|c|}{ Acidity* } \\
\hline & $6^{\text {th }}$ day & $8^{\text {th }}$ day & $10^{\text {th }}$ day & $12^{\text {th }}$ day & $15^{\text {th }}$ day \\
\hline $100 \%$ Sisnu & $0.45^{\mathrm{a}}(0.18)$ & $0.56^{\mathrm{a}}(0.14)$ & $0.67^{\mathrm{a}}(0.18)$ & $0.86^{\mathrm{a}}(0.10)$ & $0.85^{\mathrm{a}}(0.06)$ \\
\hline Sisnu with $1 \%$ salt & $0.44^{\mathrm{a}}(0.04)$ & $0.57^{\mathrm{a}}(0.16)$ & $0.68^{\mathrm{a}}(0.10)$ & $0.85^{\mathrm{a}}(0.08)$ & $0.85^{\mathrm{a}}(0.08)$ \\
\hline Sisnu with $1 \%$ sugar & $0.58^{\mathrm{b}}(0.12)$ & $0.75^{\mathrm{b}}(0.10)$ & $0.82^{\mathrm{b}}(0.13)$ & $0.91^{\mathrm{b}}(0.08)$ & $0.90^{\mathrm{b}}(0.14)$ \\
\hline Sisnu with $1 \%$ salt and $1 \%$ sugar & $0.57^{\mathrm{b}}(0.14)$ & $0.76^{\mathrm{b}}(0.04)$ & $0.80^{\mathrm{b}}(0.02)$ & $0.92^{\mathrm{b}}(0.10)$ & $0.91^{\mathrm{b}}(0.06)$ \\
\hline
\end{tabular}

* Means with same superscripts in same row are not significantly different $(\mathrm{p}<0.05)$. The figures in parentheses are the standard deviations

Table 5. Sensory results of Sisnu-Gundruk products

\begin{tabular}{lllll}
\hline Sensory attributes* & $\begin{array}{l}\text { Sisnu } \\
\text { (Control) }\end{array}$ & Sisnu with 1\% salt & $\begin{array}{l}\text { Sisnu with 1\% } \\
\text { sugar }\end{array}$ & $\begin{array}{l}\text { Sisnu with 1\%salt and } \\
\mathbf{1 \%} \text { sugar }\end{array}$ \\
\hline Color & $8.2^{\mathrm{a}}(0.04)$ & $8.4^{\mathrm{a}}(0.12)$ & $8.5^{\mathrm{a}}(0.10)$ & $8.3^{\mathrm{a}}(0.08)$ \\
Flavor & $6.8^{\mathrm{a}}(0.12)$ & $7.2^{\mathrm{a}}(0.04)$ & $8.4^{\mathrm{b}}(0.16)$ & $8.2^{\mathrm{b}}(0.12)$ \\
Taste & $6.5^{\mathrm{a}}(0.10)$ & $7.7^{\mathrm{b}}(0.14)$ & $8.4^{\mathrm{b}}(0.14)$ & $8.0^{\mathrm{b}}(0.12)$ \\
\hline
\end{tabular}

* Means with same superscripts in rows are not significantly different $(\mathrm{p}<0.05)$. The figures in parentheses are the standard deviations

\section{Conclusion}

A Gundruk like fermented Sisnu product termed as SisnuGundruk could be produced by lactic fermentation; however a slightly putrid flavor was noticed due to high protein content in fresh Sisnu leaves. Addition of salt (1\%) or salt and sugar ( $1 \%$ each) could increase the acidity of Sisnu-Gundruk. Contrarily, the $\mathrm{pH}$ of Sisnu-Gundruk was not changed significantly during fermentation. Due to the optimum flavor and acidity, both types of products i.e. product with $1 \%$ salt as well as product with $1 \%$ sugar and $1 \%$ salt were highly preferred by sensory evaluation.

Further research can be made as comparative study on the natural and pure culture fermentation of Sisnu-Gundruk. For the next the storage stability of fermented fresh-Sisnu or Sisnupickle by using different hurdle technologies also can be studied.

\section{References}

Chopra A. and Bhargava D. (1958). Nettle, a medicinal herb. Indian J. agric. Sci., 32B: 297.

Frohlich R. H., Kunze M. and Kiefer I. (1997). Cancer Preventive Impact of naturally occurring, Non- nutritive Constituents in Food. In: Acta Medica Austriaca, Acta Medica Austriaca Publication, Austria, pp 72, 74

Griffith K. G. (1996). Grasping the nettle, In: Herbal Extract and Tinctures. Research Committee of the Tennessee Exotic Pest Plant Council, Tennessee, pp 135.

Kavalali G. (2003). Urtica. In: Therapeutic and Nutritional aspects of Stinging Nettles, Taylor and Francis, London, pp $24,25,26$

Manandhar N. P. and Maheshwari G. (2000). Plants and people of Nepal. Bhundi Puran Publication, Kathmandu, Nepal, pp 47, 64 .

Rangana S. (2000). Handbook of Analysis and Quality Control for Fruits and Vegetable Products, CBS Publication, India.

Swaminathan M. (2003). Food and Nutrition Volume II, CBS Publication, India. 